\title{
A NIGERIAN CASED-BASED STUDY OF NON-VALUE ADDING ACTIVITIES AND THEIR REDUCTION IN CONCRETE PAVER PRODUCTION
}

\author{
Adefemi Aka ${ }^{1}$ and Fidelis Emuze ${ }^{2}$
}

\begin{abstract}
Waste is responsible for certain production problems in construction. The negative impact of waste has spurned its reduction related studies. However, previous studies have not addressed the impact of waste on the production of concrete pavers in a factory. This paper thus reports on a case-based study that was conducted in selected concrete pavers' (CPs) factories in Nigeria to investigate the various waste in the production process.

Typical forms of waste that were discovered in the study are excessive procurement of materials, unnecessary delay, not meeting up with the daily production schedule and over curing of concrete pavers. The initial results calls for the adoption of lean practices that will reduce waste and improve production outputs in the factories. There is a major scope for the use of Kanban, JIT, and other lean tools in the case production settings.
\end{abstract}

\section{KEYWORDS}

Lean construction, concrete pavers, process, production pull, waste.

\section{INTRODUCTION}

The concept of concrete pavement started in the late 1940s in the Netherlands as a replacement for clay brick streets. In the mid-70s, automated concrete pavement production was introduced in North America. Nowadays, CPs are manufactured with highly controlled production equipment in controlled environments resulting in paving units with close tolerances to help ensure pavement interlock (Brozovsky et al. 2005; Osman et al. 2012; Ravikumar et al. 2012). The use of CPs for municipal applications is well accepted (Smith 1992).

The proportions of any mixture used for the production of CPs depend on locally available materials, manufacturing equipment requirements, the desired final texture and quality of the paving unit (Muraleedharan and Sood 2003; Kashiyani et al. 2013). In Nigeria, concrete pavers (CPs) are produced with mixtures of sand or crusher dust, cement, dyes and curing agent which make them suitable as finishing material in external flooring of buildings. In the factory, CPs are made by pouring of concrete and some type of colouring agent in a mould. The mixtures are allowed to set over some time. CPs are available in a wide range of surface texture, colours, finishes, shape and other special

1 Lecturer, Department of Building, Federal University of Technology, Minna, Niger State, Nigeria, aka.femi@futminna.edu.ng, orcid.org/0000-0002-5926-9843

2 Professor, and Head, Department of Built Environment, Central University of Technology, Free State, South Africa, femuze@cut.ac.za, orcid.org/0000-0001-7714-4457 
features which makes the product suitable for varying design possibilities (Adewuyi and Odesola 2015).

A concrete paver is versatile, aesthetically attractive, functional, and cost-effective. It requires limited or no maintenance, if adequately manufactured and fixed (Muraleedharan and Sood 2003). According to Smith (1992), some of the properties of a typical concrete paver include:

- Durable: a concrete paver should be able to withstand abrasion, impact and chemical attack.

- It should be of uniform dimensions to facilitate correct and easy placing and ensure excellent ride ability.

- It should be aesthetically attractive.

Despite the benefit of CPs advocated in the reviewed literature, its production process generates increasingly quantities of waste or non-value adding activities (NVAAs) that shoot up production cost, and decrease the profitability of the venture (Adewuyi and Odesola 2015).

As a result of the pervasiveness and impact of NVAAs, researchers have investigated how to reduce and eliminate them in the construction and production processes (Koskela 1992; Osmanu 2011; Marzouk et al. 2011; Zoya-Kpamma and Adjei-Kumi 2011; Gatlin 2013; Ko and Chung 2014). However, the aspect of the manufacturing process, where projects cost can further be effectively reduced, has not been extensively covered. Therefore, this study was conducted in some selected CPs manufacturing factories in Nigeria to investigate the various NVAAs and their causes in the production process of concrete pavers (PPCPs).

\section{OVERVIEW OF NVAAS AND LEAN PRACTICES}

NVAAs can be defined as wasted efforts that consume time and resources without directly or indirectly adding value to project requirements (Han 2008). In the context of this paper, they are the operations that do not add value to the concrete pavers but increase the overall cost of the product. Therefore, they can be termed as wastes in the production process (Forbes and Ahmed 2011). NVAAs in the production process has been the subject of several studies (Li et al. 2008; Nagapan et al. 2012; Koskela et al. 2013).

Previous studies agree on the detrimental impact of NVAAs on production (or prject) performance. However, the impact of each NVAA differs. For instance, Ohno (1988) points out that overproduction is a NVAA that is responsible for most of the waste experienced in the mass production process. Apart from overproduction, making-do is another great waste to be considered (Koskela 2004; Koskela et al. 2013). Also, Aka et al. (2017) are of the views that making-do, design errors/mistakes and omissions are the leading causes of rework in the construction process. This implies that making-do, overproduction, errors/mistakes and omissions are major NVAAs that lead to production problems, which in turn feeds the cost and time overrun pipeline in an enterprise.

NVAAs in construction site production can be categorized into eight or more forms. These include defects (corrections), overproduction, over-processing, waiting (delay), inventory, motion, transportation and unexplored creativity of employees (Womack and Jones 2003; Sommerville 2007; Love et al. 2008; Zhanwen 2009; Lopez et al. 2010; Koskela et al. 2013). Making-do is another form of waste that could severely erode performance in a work environment (Koskela 2004). Lean practices can be applied to projects environment to eliminate NVAAs (Ahmed and Forbes 2011). 
Lean practices embodies a thinking that is aimed at providing a creative way for organizing human activities to eliminate waste and deliver more benefits and value to the society/individuals (Womack et al. 1990). Examples of the lean practices in the form of concepts, principles, tools, and techniques for waste reduction in the construction and manufacturing environments are value stream mapping (VSM), the 5 Whys, Kanban (pull systems), A3 problem-solving report, Kaizen, daily huddle meetings (DHMs), look-ahead schedule (LAS), quality assurance (QA), total quality control (TQC), and just-in-time (JIT) (Koskela 1992; Womack and Jones 2003; Liker and Morgan 2006; Holweg 2007). Despite the benefits of the aforementioned lean tools/techniques in terms of waste elimination in developed nations (Velarde et al. 2009), its adoption in the developing countries such as Nigeria is marginal. Therefore, further studies are required to investigate the benefits of lean tools in construction in developing countries.

\section{RESEARCH METHODS}

This research aims to identify the various NVAAs in PPCPs. The identification of the NVAAs and their causes will lead to the formulation of guidelines that are underpinned by lean practices. To achieve the stated goals, case-based studies were conducted in eight selected CPs production factories located in Minna, Niger State, Nigeria. Physical observation and in-depth interviews were the main methods used to collect the data. The selection of the factories for the study was based on purposive sampling techniques (Ritchie and Lewis 2003). This implies that only factories that have been established for more than five years and have staff with profound knowledge in the production of different CPs were selected for the study.

Managers and their assistants, including five labourers, were selected for the interview in each factory. The interviewees have been working together as a team for more than five years. In the case studies, the physical observation was first conducted in each factory before the interview study. This was done so as to understand the phases and activities in the PPCPs. The observations were conducted over two months (six hours per day). The data obtained in this phase assisted the researchers on the likely questions to raise in the interview phase. The questions that were asked were focused mainly on three aspects to facilitate the analysis of the anticipated data in the qualitative phase of the study. These aspects include:

- The various waste in each phase of the production of CPs,

- The causes of the waste in each phase, and

- The strategy that can be adopted to reduce the waste.

At the start of each interview, the respondents were reminded of the research aim and objectives. Each respondent was also asked of their experience as far as CPs production is concerned. The respondents were then given a short questionnaire to complete. This process was followed by the actual interview questions, which were guided by a semistructured protocol (McNamara 2009). For consistency, the interview was conducted three times in each factory, and it extended over three months. The duration of each interview session also ranged from 45 to 55 minutes. As recommend by Arksey and Knight (1999), all the interview discussions were tape-recorded and transcribed. After transcription, the resultant information was analysed using content analysis (Krippendorff 2012). The themes that were obtained from the analysed data were then validated through follow-up interviews, which were conducted by the researchers with the manager of each case study factory (McNamara 2009). 
The themes in the resulting information were further validated through the attitudinal surveys as proposed by McNamara (2009). This implies that the information obtained in the qualitative study were used to prepare a questionnaire that was administered to other CPs producers in 10 different factories that were randomly selected in the study location. The 10 selected factories have been existing for more than five years and had staff that were experienced in the production of CPs. It is essential to note that before the distribution of the main questionnaire, a pilot study was conducted in the factories. The essence of this was to find out if the questionnaire was adequately designed and would be answered by the respondents without ambiguities. Hence, the success of the pilot study enabled the researchers to proceed with the main study. The questionnaire was distributed to randomly selected staff of the selected factories. The qualifications of the respondents' ranges from secondary school certificate to first degree. It should be noted that the survey exercise in this study was not to achieve statistical generalization but to further validate the data obtained in the qualitative phase of the study (McNamara 2009). In the questionnaires distributed in each factory, participants were asked to rate the 17 discovered waste in the PPCPs and their causes based on a five-point Likert scale to measure the extent of their agreement. The collected data from the survey study were analysed through the mean item score (MIS), standard deviation (SD) and ranking method (George and Mallery 2003). Waste and their causes that have the highest MIS was ranked first, while the least was ranked last.

\section{RESULTS AND INTERPRETATIONS}

\section{QuALITATIVE DATA}

Based on the physical observations and interviews conducted in this study, it was discovered that the PPCPs encompasses seven different phases. These include the raw materials procurement phase, where the materials (sand or crusher dust, cement, dyes and curing agent) used for the production of CPs are sourced and transported to the production factory. Participants in all the factories emphasized that production materials are separately stored. The materials were well-drained before they are needed for production, and are also protected from rain to remain reasonably dry to avoid high workability that can affect the strength of the product. The batching phase is where the site engineer/manager determines the quantity of each material required for the production of a specified number of CPs. The material mixing phase is where the sand or crusher dust, cement, dyes (if required) and curing agent are discharged separately or simultaneously, and thoroughly mixed before the addition of water.

After the materials have been adequately mixed with water, the mixture will be stored in hoppers to be ready to be dispensed into different moulds that have different thickness but of the same shapes. In the mould filling phase, the stored mixtures in hoppers are transferred into the moulds. After that, they are progressively compacted under vibration until a predetermined strength has been achieved. The drying phase is where the products are left in an open space to dry for a period before curing adequately. The curing phase is where the newly produced CPs are cured for specific days to obtain the required strength needed for construction. It is essential to note that in all the factories visited during this study, two curing methods were observed. The methods are the water sprayers and the immersion type. The storing phase is where the newly produced CPs are temporarily arranged before supplying them to the clients. In all the case study factories, supply is demand driven. The last phase is the transportation phase, where the products are moved 
from the factory to the construction site. Based on the physical observations and the interviews conducted, the NVAAs discovered in the PPCPs, and their causes are outlined in Table 1.

Table 1: NVAAs in the Production Process of Concrete Pavers

\begin{tabular}{|c|c|c|}
\hline $\begin{array}{l}\text { Production } \\
\text { phase }\end{array}$ & NVAAs and their descriptions & Categories of waste \\
\hline $\begin{array}{l}\text { Raw materials } \\
\text { procurement } \\
\text { phase }\end{array}$ & $\begin{array}{l}\text { Excessive procurement of sand or } \\
\text { crusher dust, cement, dyes and } \\
\text { curing agent due to unanticipated } \\
\text { material requirements }\end{array}$ & Over-production \\
\hline Batching phase & $\begin{array}{l}\text { Long-distance covered from the } \\
\text { location where the production } \\
\text { materials are temporarily kept to } \\
\text { the batching location due to } \\
\text { inadequate factory design (layout) } \\
\text { and excessive concrete mixture } \\
\text { due to negligence or human error }\end{array}$ & $\begin{array}{l}\text { Transportation and over- } \\
\text { processing }\end{array}$ \\
\hline $\begin{array}{l}\text { Material mixing } \\
\text { phase }\end{array}$ & $\begin{array}{l}\text { Delay in the new mix due to } \\
\text { inaccurate information from the } \\
\text { production manager, excessive } \\
\text { waiting due to longer mixing time } \\
\text { for products that require smoother } \\
\text { surfaces and not meeting up with } \\
\text { the daily production target or } \\
\text { schedule due to several } \\
\text { unnecessary waiting while } \\
\text { production has already started }\end{array}$ & Waiting time \\
\hline $\begin{array}{l}\text { Mould filling } \\
\text { phase }\end{array}$ & $\begin{array}{l}\text { A sudden crack or damage to } \\
\text { containers used to cast CPs due to } \\
\text { poor quality, recasting of some } \\
\text { CPs due to sudden damage of the } \\
\text { containers used to cast the CPs, } \\
\text { inadequate or poor compaction of } \\
\text { some CPs due to poor supervision } \\
\text { and low standard of some CPs due } \\
\text { to lack of compliance with the } \\
\text { standard specifications }\end{array}$ & Defect/correction \\
\hline Drying phase & $\begin{array}{l}\text { Over drying of the newly } \\
\text { produced CPs due to lack of } \\
\text { production control policies and } \\
\text { long-distance covered from the } \\
\text { production location to the drying } \\
\text { environment due to inadequate } \\
\text { factory design (factory layout) }\end{array}$ & $\begin{array}{l}\text { Over-processing and } \\
\text { transportation }\end{array}$ \\
\hline
\end{tabular}




\begin{tabular}{lll}
\hline Curing phase & $\begin{array}{l}\text { Excessive curing of CPs and poor } \\
\text { quality of some CPs due to lack of } \\
\text { production control policies; } \\
\text { inadequate supervision, and lack } \\
\text { of production control policies } \\
\text { made worse by poor workmanship }\end{array}$ & $\begin{array}{l}\text { Over-processing and } \\
\text { defect/correction }\end{array}$ \\
& $\begin{array}{l}\text { Long-distance covered from the } \\
\text { drying/curing position to the } \\
\text { Storing phase location due to inadequate }\end{array}$ & \\
& Transportation and inventory \\
& $\begin{array}{l}\text { factory design and excessive } \\
\text { storing of the CPs due to low } \\
\text { demands from the clients }\end{array}$ & \\
& $\begin{array}{l}\text { Breaking off (cracking) some CPs } \\
\text { while loading them into the }\end{array}$ & \\
Transportation & Defect/correction \\
phase & vehicle due to the poor quality of & \\
& the CPs. & \\
\hline
\end{tabular}

From the interviews, participants were unable to suggest a robust way of overcoming NVAAs in the PPCPs. However, the literature shows that lean principles/techniques can be applied to projects to weed out waste in the process (Womack and Jones 2003; Ko and Chung 2014). Based on the various forms of NVAAs discovered in this study, just-intime (JIT), the total quality control (TQC), Kanban, the five lean principles (value, value stream, flow, pull and perfection), standard work, A3 Problem Solving, and error proofing could enhance PPCPs in terms of efficiency. For instance, the concept of Kanban, JIT and the pull principle can be used to reduce waste due to excessive buying of materials. Also, the idea of TQC and error proofing can overcome waste due to the poor quality of CPS and excessive batching of materials.

\section{Quantitative Data}

The qualitative data were verified with a survey research as method in the research methods section. Table 2 shows the number of questionnaires distributed, and those that were returned in the survey exercise. The response rate achieved is $76.5 \%$.

Table 2: Questionnaires administration

\begin{tabular}{ccc}
\hline Factory & \multicolumn{2}{c}{ Questionnaires } \\
& Administered & Returned \\
\hline A & 15 & 10 \\
B & 12 & 11 \\
C & 9 & 9 \\
D & 13 & 13 \\
E & 11 & 10 \\
F & 14 & 11 \\
G & 11 & 9 \\
H & 13 & 7 \\
I & 17 & 12 \\
J & 17 & 9 \\
\hline Total & 132 & 101 \\
\hline
\end{tabular}


Tables 3 and 4 present the perceptions of the respondents regarding the various forms of NVAAs and their causes in the PPCPs. The high Cronbach's $\alpha$ value $(0.891$ and 0.821$)$ obtained show the reliability and acceptability of the data (Agresti and Franklin 2007). The standard deviations (SD) obtained are also within the acceptable range (George and Mallery 2003). Based on this information, it can be emphasized that statements such as not meeting up with the daily production target and excessive storing of the concrete pavers with MIS of 3.0 and above are the NVAAs perceived to be of notable in the PPCPs.

Table 3: NVAAs perceptions in the production process of concrete pavers

\begin{tabular}{|c|c|c|c|c|}
\hline Statement & $\begin{array}{l}\text { Mean } \\
\text { Item } \\
\text { Score } \\
\end{array}$ & SD & $\begin{array}{l}\text { Cronbach' } \\
\boldsymbol{\alpha}\end{array}$ & Ranking \\
\hline $\begin{array}{l}\text { Not meeting up with the daily production } \\
\text { target }\end{array}$ & 4.23 & 0.811 & 0.891 & $1^{\text {st }}$ \\
\hline Excessive storing of the concrete pavers & 4.17 & 0.799 & & $2^{\text {nd }}$ \\
\hline $\begin{array}{l}\text { Excessive procurement of sand or crusher } \\
\text { dust, cement, dyes and curing agent }\end{array}$ & 4.13 & 0.813 & & $3^{\text {rd }}$ \\
\hline Excessive waiting time & 4.07 & 0.813 & & $4^{\text {th }}$ \\
\hline $\begin{array}{l}\text { Long-distance covered from the location } \\
\text { where the production materials are } \\
\text { temporarily kept to the batching location }\end{array}$ & 3.71 & 0.892 & & $5^{\text {th }}$ \\
\hline Excessive concrete mixture & 3.53 & 0.915 & & $6^{\text {th }}$ \\
\hline $\begin{array}{l}\text { Inadequate or poor compaction of some } \\
\text { concrete pavers }\end{array}$ & 3.31 & 0.978 & & $7^{\text {th }}$ \\
\hline Excessive curing of concrete pavers & 2.96 & 1.178 & & $8^{\text {th }}$ \\
\hline A recasting of concrete pavers & 2.72 & 0.962 & & $9^{\text {th }}$ \\
\hline The poor quality of some concrete pavers & 2.65 & 0.998 & & $10^{\text {th }}$ \\
\hline $\begin{array}{l}\text { Breaking off (cracking) some concrete } \\
\text { pavers while loading them into the vehicle. }\end{array}$ & 2.57 & 1.098 & & $11^{\text {th }}$ \\
\hline The poor quality of some concrete pavers & 2.51 & 1.219 & & $12^{\text {th }}$ \\
\hline Excessive delay in every new mix & 2.12 & 0.981 & & $13^{\text {th }}$ \\
\hline $\begin{array}{l}\text { Long-distance covered from the } \\
\text { drying/curing position to the storing } \\
\text { location }\end{array}$ & 1.73 & 1.276 & & $14^{\text {th }}$ \\
\hline $\begin{array}{l}\text { A sudden damage of the containers used to } \\
\text { cast concrete pavers }\end{array}$ & 1.71 & 1.217 & & $15^{\text {th }}$ \\
\hline $\begin{array}{l}\text { Over drying of the newly produced } \\
\text { concrete pavers }\end{array}$ & 1.67 & 1.214 & & $16^{\text {th }}$ \\
\hline $\begin{array}{l}\text { Long-distance covered from the production } \\
\text { location to the drying environment }\end{array}$ & 1.55 & 1.298 & & $17^{\text {th }}$ \\
\hline
\end{tabular}


In contrast, NVAAs with less than 2.9 such as over-drying of the newly produced CPs and long-distance covered from the production location to the drying environment could be deemed to be less significant (Sabine 2004). The remedies should therefore target the significant NVAAs in PPCPs. In other words, lean practices that will be appropriate for tackling missing daily production target, excess inventory, overproduction, waiting time, processing time, and transportation (or logistics) is required to reduce NVAAs in the selected CP factories.

Concerning the causes of the observed NVAAs, statements such as inadequate supervision, deviation from specifications, long mixing time (over processing), human error, wrong information, poor quality and poor factory layout are notable (Table 4). These notable causes have to be addressed by managers and workers in the factories through appropriate lean concepts and principles. The use of lean culture is significant here as it connects tools to business objectives (Rubrich 2012). "Lean culture is the component that makes it all happen, the component that musters the organisation's most important resource -its people-to create an organisational 'war on wasteful activities' (Rubrich 2012: 51)".

Table 4: Causes of NVAAs in the production process of concrete pavers

\begin{tabular}{|c|c|c|c|c|}
\hline Statement & $\begin{array}{l}\text { Mean } \\
\text { Item } \\
\text { Score }\end{array}$ & SD & $\begin{array}{c}\text { Cronbach' } \\
\alpha\end{array}$ & Ranking \\
\hline Poor supervision & 4.26 & 0.831 & 0.821 & $1^{\text {st }}$ \\
\hline Deviation from specifications & 4.13 & 0.876 & & $2^{\text {nd }}$ \\
\hline $\begin{array}{l}\text { Longer mixing time for products that } \\
\text { require smoother surfaces }\end{array}$ & 4.10 & 0.751 & & $3^{\text {rd }}$ \\
\hline Low demands from the customers & 3.89 & 0.967 & & $4^{\text {th }}$ \\
\hline Negligence or human error & 3.71 & 0.987 & & $5^{\text {th }}$ \\
\hline $\begin{array}{l}\text { Inaccurate information from the production } \\
\text { manager }\end{array}$ & 3.65 & 0.972 & & $6^{\text {th }}$ \\
\hline Poor quality of some concrete pavers & 3.62 & 0.875 & & $7^{\text {th }}$ \\
\hline Poor factory design (layout) & 3.59 & 0.981 & & $8^{\text {th }}$ \\
\hline $\begin{array}{l}\text { The poor quality of the containers used to } \\
\text { cast concrete pavers }\end{array}$ & 2.53 & 1.112 & & $9^{\text {th }}$ \\
\hline Lack of production control policies & 2.51 & 1.198 & & $10^{\text {th }}$ \\
\hline Sudden (unanticipated) material demand & 1.57 & 1.231 & & $11^{\text {th }}$ \\
\hline
\end{tabular}




\section{CONCLUSIONS}

The discourse in this paper suggests that NVAAs exist in the production of CPs in the case factories. Examples of such waste are excessive procurement of materials, delay/excessive waiting, not meeting up with the daily production target or schedule, refilling of moulds, inadequate or poor compaction of some CPs, long-distance covered from the production location to the drying environment, excessive curing of CPs, and excessive storing of CPs. The significant causes of the identified NVAAs in the PPCPs are poor factory design, deviation from specifications, inadequate supervision, and negligence or human error. When viewed in the light of the eight classical waste and their causes, the aforementioned are consistent with the findings of Yahia (2004), Mossman (2009), Nagapan et al. (2012), and Gatlin (2013) regarding waste and their causes in the construction process.

Based on the above thinking, the use of specific lean practices will serve the production and profit interest of the case factories. The research team thus tentatively recommends lean tools such as Kanban, JIT, and TQC for waste elimination in the production process of concrete pavers in Nigeria. The concept of Kanban, JIT and the pull principle can be used to reduce waste due to excessive buying of materials in the factories. While the idea of TQC and error proofing can be applied to overcome waste due to poor quality of CPs and excessive batching of materials.

However, the practicality of the suggestions in the PPCPs is presently being examined in one of the case study factories. The research team in collaboration with the management of one of the factories is selectively deploying the lean practices to see if a major performance improvement will emerge. The outcome of deployment of lean practices in this case factory will be shared with the community.

Future studies could investigate the percentage of the discovered waste and their cost implication on concrete pavers' factory. Such studies will build upon the current effort on the assessment of the appropriate lean practices for use in the CP factories in Nigeria.

\section{ACKNOWLEDGMENTS}

We would like to thank in advance all reviewers for their positive feedback on how to improve the paper. We would also like to thank the industry participants in the study.

\section{REFERENCES}

Adewuyi, T. O and Odesola, I. A. (2015). Factors affecting material Waste on construction sites in Nigeria. Journal of Engineering and Technology, 6(1), 32-35.

Agresti, A. and Franklin, C. 2007. Statistics: The Art and Science of Learning from Data. Pearson Prentice-Hall, Upper Saddle River, NJ.

Aka, A., Emuze, F., and Das, D. (2017). Mapping waste in the structural design process in South African projects. In: LC3 2017 Volume II - Proceedings of the 25th Annual Conference of the International Group for Lean Construction (IGLC), Walsh, K., Sacks, R., Brilakis, I. (eds.), Heraklion, Crete, Greece pp. 475-482.

Arksey, H., and Knight, P. (1999). Interviewing for social scientists: an introductory resource with examples. London: Sage.

Brozovsky, J., Matejka O., and Martinec, P. (2005). "Concrete interlocking paving blocks compression strength determination using non-destructive methods". The $8^{\text {th }}$ International Conference of the Slovenian Society for Non-Destructive Testing, ISSN: 00088846, 91-97. 
ElReifi, M.H., and Emmitt, S. (2013). Perception of lean design management. Architectural Engineering and Design Management Journal, 9(3), pp. 195-208.

Forbes, L. H., and Ahmed, S. M. (2011). Modern construction: Lean project delivery and integrated practices. Boca Raton: CRC Press.

Gatlin, F. (2013). Identifying and managing design and construction defects. Navigant Consulting, Inc. Pp. 1-11.

George, D. and Mallery, P. 2003. SPSS for Windows Step by Step: A Simple Guide and Reference-11.0 Update, 4th ed., Allyn \& Bacon, Boston, MA.

Han, S. (2008). "A hybrid simulation model for understanding and managing non-value adding activities in large-scale design and construction projects", unpublished PhD thesis, the University of Illinois at Urbana-Champaign, Champaign, IL.

Holweg, M. (2007). The genealogy of lean production. Journal of Operations Management, 25(2): 420-437.

Kashiyani, B. K., Pitroda, J., and Shah, B. (2013). "Innovative addition of polypropylene fibre in interlocking paver block to improve compressive strength". International Journal of Civil, Structural, Environmental and Infrastructure Engineering Research and Development, 3(2), 17-26.

Ko, C. H. and Chung, N. F. (2014). Lean design process. Journal of Construction Engineering and Management, 4(3): 464-468.

Koskela, L. J. (1992). Application of the new production philosophy to construction. Technical Report No.72 Stanford, CA: Centre for Integrated Facility Engineering, Stanford University.

Koskela, L.J. (2004). Making do-the eighth category of waste. In: Proceedings of the 12th Annual Conference of the International Group for Lean Construction. Helsingor, Denmark, August 2004, pp. 2-3.

Koskela, L. J., Bolviken, T., and Rooke, J. A. (2013). Which are the wastes of construction? In: Proceedings of the 21st Annual Conference of the International Group for Lean Construction. Fortaleza, Brazil, August 2013. P. 3-12.

Krippendorff, K. (2012). Content analysis: an introduction to its methodology. London: Sage.

Li, H., Huang, T., Kong, C. W., Guo, H. L., Baldwin, A., Chan, N., and Wong, J. 2008. Integrating design and construction through virtual prototyping. Automation in Construction, 17(8): 915-922.

Liker, J.K., and Morgan, J.M. (2006). The Toyota Way in Services: The case of lean product development. Academy of Management Perspectives, 20(2), pp. 5-27.

Lopez, R., Love, P. E. D., Edwards, D. J., and Davis, P. R. (2010). "Design error classification, causation, and prevention in construction engineering", Journal of Performance of Constructed Facilities, 24(4): 399-408.

Love, P.E.D., Edwards, D.J., and Irani, Z. (2008). Forensic project management: an exploratory examination of the causal behaviour of design-induced rework. IEEE Transaction on Engineering Management, 55(2), pp. 234-247.

Marzouk, M., Bakry, I., and El-Said, M. (2011). Application of lean principles to design processes in construction consultancy firms. International Journal of Construction Supply Chain Management, 1(1): 43-55.

McNamara, C. (2009). General guidelines for conducting research interviews. Retrieved January 11, 2016, from http://managementhelp.org/evaluatn/intrview.htm.

Mossman, A. (2009). 'Why isn't the UK construction industry going lean with gusto?' Lean Construction Journal, 5(1): 24-36. 
Muraleedharan, T., and Sood, V. K. (2003). "Past and present efforts for the popularization of interlocking concrete block pavement technology in India". Proceedings of the 7th International Conference on Concrete Block Paving, ISBN Number: 0-958-4609 1-4.

Nagapan, S, Rahman, I. A, Asmi, A., Memon, A. H., and Zin, R. M. (2012). Identifying causes of construction waste: Case of Central Region of Peninsula Malaysia. International Journal of Integrated Engineering, 4(2): 22-28.

Ohno, T. (1988). The Toyota Production System: Beyond large-scale production. Portland, Oregon: Productivity Press.

Osmani, M. (2011). Construction waste. In: Letcher, T.M. and Vallero, D.A. Edition. Waste: A Handbook for Management. P. 207-218.

Ravikumar, M. C., Anilkumar, H., Prashanth M., and Venkat, D. R. (2012)."Experimental studies on iron ore tailing based interlocking paver", International Journal of Earth Sciences and Engineering, 5(3), 501-504.

Ritchie, J., Lewis, J., and Elam, G. (2003). Designing and selecting samples. In Ritchie, J. and Lewis, J., 2003 (edited). Qualitative research practise A guide for social science students and researchers. London: Sage.

Rubrich, L. 2012. An introduction to Lean Construction: applying lean to construction organizations and processes. Fort Wayne, IN: WCM Associates.

Sabine, Landau and Braine, S. Everitt, 2004. A handbook of statistical analysis using SPSS. Chapman and Hall/CRC Press LLC, Washington, D.C.

Smith D. R. (1992). The institutionalization of concrete Block Pavements in North America. Fourth International Conference on Concrete Block Paving, Porirua, New Zealand, 1, 355-359.

Sommerville, J. (2007). Defects and rework in the new build: An analysis of the phenomenon and drivers. Structural Survey Journal, 25(5), pp. 391-407.

Womack, J.P., Jones, D.T., and Roos, D. (1990). The machine that changed the world: based on Massachusetts. Institute of Technology 5-million dollar 5-year study on the future of the automobile. New York: Rawson Associates.

Womack, J. P., and Jones, D. T. (2003). Lean Thinking-Banish Waste and Create Wealth in Your Corporation. 2nd edition, London: Simon and Schuster.

Yahia, A. (2004). Time Schedule Preparation by Predicting Production Rate Using Simulation", MSc Thesis in Construction Management, Islamic University of Gaza.

Zhanwen, N. (2009). Lean design and management for manufacturing enterprise lifecycle. Economic Research Centre Discussion. Paper No. 174, pp. 1-13.

Zoya-Kpamma, E., and Adjei-Kumi, T. (2011). Management of waste in the building design process: The Ghanaian Consultants Perspective. Journal of Architectural Engineering and Design Management, 7(1): 102-112. 